\title{
Sea scallop larvae Placopecten magellanicus on Georges Bank: vertical distribution in relation to water column stratification and food
}

\author{
M. John Tremblay ${ }^{1}$, Michael Sinclair ${ }^{2}$ \\ ' Fisheries and Oceans, Biological Sciences Branch, PO Box 550, Halifax, Nova Scotia, Canada B3J 2S7 \\ ${ }^{2}$ Bedford Institute of Oceanography, PO Box 1006, Dartmouth, Nova Scotia, Canada B2Y 4A2
}

\begin{abstract}
Vertical distribution of sea scallop larvae was studied from pump samples in mixed, stratified, and frontal areas of Georges Bank. The extent of larval aggregation was positively related to the degree of water column stratification. In mixed areas larvae were distributed evenly over the 40 to $50 \mathrm{~m}$ water column, while in stratified waters larvae showed subsurface peaks in concentration above the pycnocline. Where the pycnocline was well developed, differences in the larval centre of mass (ZCM) were associated with differences in the position of the pycnocline. Food for sea scallop larvae was measured as the concentration of chlorophyll $a<15 \mu \mathrm{m}$ and particles 2.5 to $16 \mu \mathrm{m}$. In stratified areas food was usually greatest within the upper $10 \mathrm{~m}$. Sea scallop larvae were most concentrated below $10 \mathrm{~m}$ and did not aggregate in relation to food concentration. The capacity of sea scallop larvae for depth regulation on Georges Bank appears limited, since there were no diel differences in the ZCM, and sizedependent differences in vertical distribution were weak and inconsistent.
\end{abstract}

\section{INTRODUCTION}

How marine planktonic larvae are vertically distributed in the water column is fundamental to understanding their dispersal patterns, but studies of the vertical distribution of single species of bivalve larvae on continental shelves are rare (Mann 1985, 1986, Tremblay \& Sinclair 1988), perhaps because of problems with identification and logistics. What we know about the vertical distribution of bivalve larvae in nature is restricted largely to estuarine and nearshore species (e.g. Nelson \& Perkins 1931, Carriker 1951, Korringa 1952, Quayle 1952, 1959, Kunkle 1958, Verwey 1966, Wood \& Hargis 1971, Drinnan \& Stallworthy 1979, Boicourt 1982, Seliger et al. 1982, Andrews 1983, Harding et al. 1986, Mann 1988a) which inhabit environments very different from that of the continental shelf.

Since bivalve larvae have a specific gravity of about 1.3 (Mann 1986) the fact that they are planktonic indicates either strong physical mixing, or active swimming. Active swimming implies the possibility of vertical migration and depth regulation, defined here as the maintenance of a depth range where preferred temperatures, food, or other conditions are met. Depth regulation by bivalve larvae on continental shelves may be less prevalent than in estuarine larvae, which live in environments characterized by sharp vertical gradients in temperature and salinity. Several laboratory studies suggest that bivalve larvae which inhabit deeper environments are less pressure sensitive, and thus less likely to depth regulate (Cragg 1980, Mann 1986, 1988a). Nevertheless depth regulation by bivalve larvae on continental shelves is suggested by diel differences in depth (Scrope-Howe \& Jones 1986), and by finding larvae in nature at depths predicted from laboratory study of temperature preference (Mann 1986). Lack of depth regulation by bivalve larvae is suggested where larvae are well mixed over the water column (ScropeHowe \& Jones 1986), and where larvae are not found at depths corresponding to their preferred temperature (Mann 1986). The conditions of transition from active depth regulator to passive particle are poorly defined for the larvae of Arctica islandica (Mann 1986), and the same can be said for the sea scallop larvae Placopecten magellanicus, the subject of the present study. Active depth regulation is suggested in a shallow area, where a small amplitude vertical migration occurs (Tremblay \& Sinclair unpubl.), and inability to regulate depth is suggested by distribution over the whole water column in areas where there is no thermocline (Tremblay \& 
Sinclair 1988). In areas with a thermocline sea scallop larvae are aggregated below the surface, at depths of 5 to $20 \mathrm{~m}$, but the factors influencing the subsurface aggregation of larvae are not well understood.

Bivalve larvae are aggregated in the region of the subsurface chlorophyll maximum at night at some locations in the Irish Sea (Scrope-Howe \& Jones 1986). Other zooplankton groups aggregate in relation to subsurface chlorophyll maxima (or the closely associated production maxima), depending upon species, life stage and oceanographic regime (Anderson et al. 1972, Hargreaves 1981, Longhurst \& Herman 1981, Ortner et al. 1981, Bird 1983, Southward \& Barrett 1983, Sameoto 1984. Townsend et al. 1984. Scrope-Howe \& Jones 1986). Sea scallop larvae occur in the Gulf of Maine and Georges Bank area, where subsurface chlorophyll maxima are present under certain conditions (Hargreaves 1981, Sameoto 1984, Townsend et al. 1984 , O'Reilly et al. 1987).

Size-fractionated chlorophyll should be better than bulk chlorophyll as an indicator of food for sea scallop larvae, since this species and other bivalve larvae grow on a diet of small phytoplankters $(<10 \mu \mathrm{m})$ in hatcheries (Loosanoff \& Davis 1963, Culliney 1974, Walne 1974, Bayne 1983, Carriker 1986). To what extent bivalve larvae in nature can utilize other food sources has not been critically assessed (Mann 1988b) but in controlled environments they can utilize dissolved organic matter (Rice et al. 1980. Manahan \& Crisp 1982. Marshall \& Lee 1990), and other invertebrate larvae can feed on bacteria (Rivkin et al. 1986). Ongoing studies of the feeding of sea scallop larvae on Georges Bank indicate that sea scallop larvae actively graze on phytoplankton less than $30 \mu \mathrm{m}$ in size (D. V.S Rao, Bedford Institute of Oceanography, unpubl. data)

The present study investigates the relationships among the vertical distribution of sea scallop larvae, their food, and physical variables on Georges Bank. The specific objectives are to establish the conditions associated with subsurface aggregations, to determine if there is an association between sea scallop larvae and their food, and to assess the potential role of active depth regulation via swimming in sea scallop larvae.

\section{METHODS}

Georges Bank was sampled in 1986 and 1987 during October, when sea scallop larvae are at or near their peak abundance. A total of 8 stations were occupied in different regions of the bank, after first establishing the presence of sea scallop larvae. Three stations (M1, M2, M3) were occupied in the central, shallow $(<50 \mathrm{~m})$ part of the bank, which is characterized by vertically wellmixed waters (Flagg 1987); 4 stations (S1, S2a, S2b, S3) were occupied in the deeper ( 60 to $90 \mathrm{~m}$ ) waters of the eastern part, which have some density stratification; and 1 station (F1) was occupied on the Northern Flank, a frontal region where the water column alternates between strong and weak stratification (Fig. 1).

Certain constraints exist when sampling with a pump in a tidally energetic area such as Georges Bank. Anchoring is not an option where currents are strong because the large surface area of the hose prevents it from reaching the deeper sampling intervals. For most profiles sampling was carried out while drifting with the ship engine off, periodically returning to the starting location. Profiles took an average of $74 \mathrm{~min}$ to complete $(\mathrm{SD}=16.6)$.

Pump system. The pump system used for sampling scallop larvae consists of an electric centrifugal pump (FLYGT model 2051) capable of delivering 250 to 4001 $\mathrm{min}^{-1}, 6 \mathrm{~cm}$ suction hose, and an in-line paddlewheel flowsensor and readout (SIGNET). The pump intake attached to a hydrographic wire, was moved up and down within each depth interval until a sample of 2 to $3 \mathrm{~m}^{3}$ was obtained. In 1986 the depth of the pump intake was controlled with an electronic meter block and inclinometer, while in 1987 the depth of the pump intake was controlled from a CTD readout (see below) The standard width of the depth intervals was $10 \mathrm{~m}$. Intervals less than $10 \mathrm{~m}$ were sometimes sampled in the region of the pycnocline, or when conditions prevented deeper sampling. Interval widths greater than $10 \mathrm{~m}$ were used to sample below 50 to $60 \mathrm{~m}$, to a maximum depth of $80 \mathrm{~m}$. Part of the bottom $10 \mathrm{~m}$ of the water column was always sampled in water columns with

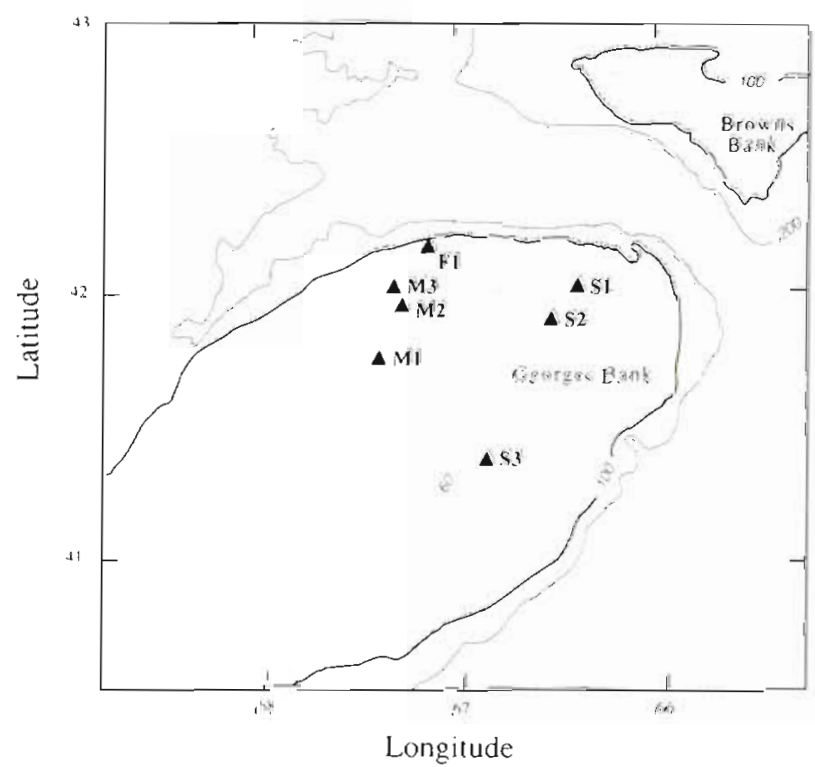

Fig. 1 Locations of drift sampling on Georges Bank during 1986 ind 1987 ' $S$ ' indicates a stratified station, 'M a mixed station, and ' $F$ ' a frontal station. Location S2 was occupled Iwice (Stns S2a and S2b in text). Isobaths are in meters 
depths less than $50 \mathrm{~m}$, but not in water columns greater than $60 \mathrm{~m}$

On deck, the pump outflow was directed first through a coarse mesh net $(333 \mu \mathrm{m})$ to remove larger particles, and then through an $85 \mu \mathrm{m}$ mesh net for sample collection. Larval samples were preserved in $4 \%$ formalin buffered with sodium borate. Methods for processing the samples and identifying larval sea scallops are described in Tremblay et al. (1987). Total counts were done on ca $75 \%$ of the samples; where larvae numbered greater than ca 400 , the sample was split with a Motoda splitter such that a total of at least 200 larvae were counted. The coefficient of variation of such subsamples was about $10 \%(n=40)$.

Physical measurements. To characterize the water column structure, temperature and salinity were measured with a Guildline CTD in 1986 and an Applied Microsystems CTD in 1987. In 1986 physical profiling was independent of the pump profiles, while in 1987 the CTD was mounted with the pump intake within a protective steel frame allowing real time monitoring of temperature and salinity. The intake pipe extended ca $80 \mathrm{~cm}$ away from the frame and was directed into the current with a large fin on the opposite side of the frame, similar to that shown in Harris et al. (1986).

Measurements of chlorophyll $a$ and particles. Chlorophyll a from the $<15 \mu \mathrm{m}$ size fraction of seawater was used as an indicator of the quantity of living phytoplankton available as food for sea scallop larvae, while the concentration of particles between 2.5 and $16.0 \mu \mathrm{m}$ was used as an indicator of all potential food items including those which did not contain chlorophyll.

Seawater samples for chlorophyll a were obtained simultaneous to the larval scallop collections in 1987. During the sampling of each depth interval, a garden hose line, off the main pump outflow, was directed through a $160 \mathrm{um}$ screen and into 101 carboys. Duplicate subsamples for up to 4 size fractions were then withdrawn: $<160,<30,<15$ and 3 to $15 \mu \mathrm{m}$. The $<160 \mu \mathrm{m}$ fraction came straight from the carboy, while the $<30$ and $<15 \mu \mathrm{m}$ fractions were obtained after passing the seawater through 30 and $15 \mu \mathrm{m}$ screens. From each of these size fractions, an aliquot of 200 to $400 \mathrm{ml}$ was passed through a Whatman GF/F filter (effective retention $0.7 \mu \mathrm{m}$ ). The 3 to $15 \mu \mathrm{m}$ size fraction was obtained by passing the $<15 \mu \mathrm{m}$ size fraction through a $3 \mu \mathrm{m}$ Nuclepore ${ }^{(\mathbb{\Xi})}$ filter. Chlorophyll a determinations were made by the fluorometric method of Holm-Hansen et al. (1965), after treating the filters with $\mathrm{MgCO}_{3}$, and extracting the chlorophyll $a$ from the filters in acetone for at least $12 \mathrm{~h}$ at ca $1{ }^{\circ} \mathrm{C}$.

The concentration of particles with equivalent spherical diameters from 2.5 to $16.0 \mu \mathrm{m}$ was determined from the $<160 \mu \mathrm{m}$ size fraction of seawater for some profiles using a Coulter Counter Model TA2. The $70 \mu \mathrm{m}$ aperture used with the Coulter Counter quantified particles with sizes from 1.0 to $32.0 \mu \mathrm{m}$, but the lowest 4 channels $(1.0,1.3,1.6,2.0 \mu \mathrm{m})$ gave unreliable readings.

Data analyses. To reflect the mean depth of sea scallop larvae and of chlorophyll a for any given profile, the centre of mass (ZCM) was calculated as follows (after Fortier \& Leggett 1982):

$$
\mathrm{ZCM}=\sum_{i=1}^{n} p_{i} z_{1}
$$

where $p_{1}=$ the proportion of the total number of larvae caught within the ith depth interval; and $z_{i}=$ the middepth of the ith interval. Depth intervals below $50 \mathrm{~m}$ were not included in the calculations, because sampling often did not include depths greater than $50 \mathrm{~m}$. Where the depth intervals were not of equal width, wider intervals were given more weight in the calculation of the ZCM, a practice also followed in calculations of water column averages

Indices of the depth of the pycnocline $(\mathrm{P})$ and the extent of density stratification (S) were calculated as follows. $\mathrm{P}$ was taken as the centre of the $10 \mathrm{~m}$ interval where the change in sigma-t was maximum. $S$ was calculated as:

$$
\mathrm{S}=\Delta \text { sigma }-\mathrm{t} / \Delta \mathrm{z}
$$

where $\Delta \mathrm{z}=$ the difference between $1 \mathrm{~m}$ and the greatest depth sampled or $50 \mathrm{~m}$, and $\Delta$ sigma-t is the difference in sigma-t over the interval $\Delta z$.

\section{RESULTS}

\section{Water column structure}

The 2 to 6 profiles within each 'station' occurred over several 10's of $\mathrm{km}^{2}$, because of ship drift during sampling (Fig. 2). Total distance drifted was related both to the currents in the area, and to whether or not the ship returned to the starting location after each profile was completed. Wind changed little between profiles (Table 1), and cannot explain the regular changes in drift direction during the 12 to 24 h of sampling at any one station. Although between-profile differences in location were sometimes substantial, the changes in water column structure and bottom depth during profiling were minimal. Initial and composite profiles of temperature and density were usually very similar (Figs. 3 to 8 ), and bottom depths did not vary by more than $\pm 5 \mathrm{~m}$ during 36 of the 41 profiles.

Density stratification was well developed only at the frontal station (F1), where substantial differences in pycnocline depth between profiles were observed (Fig. 5). At the other stratified stations (Figs. 3, 6, 8 and 


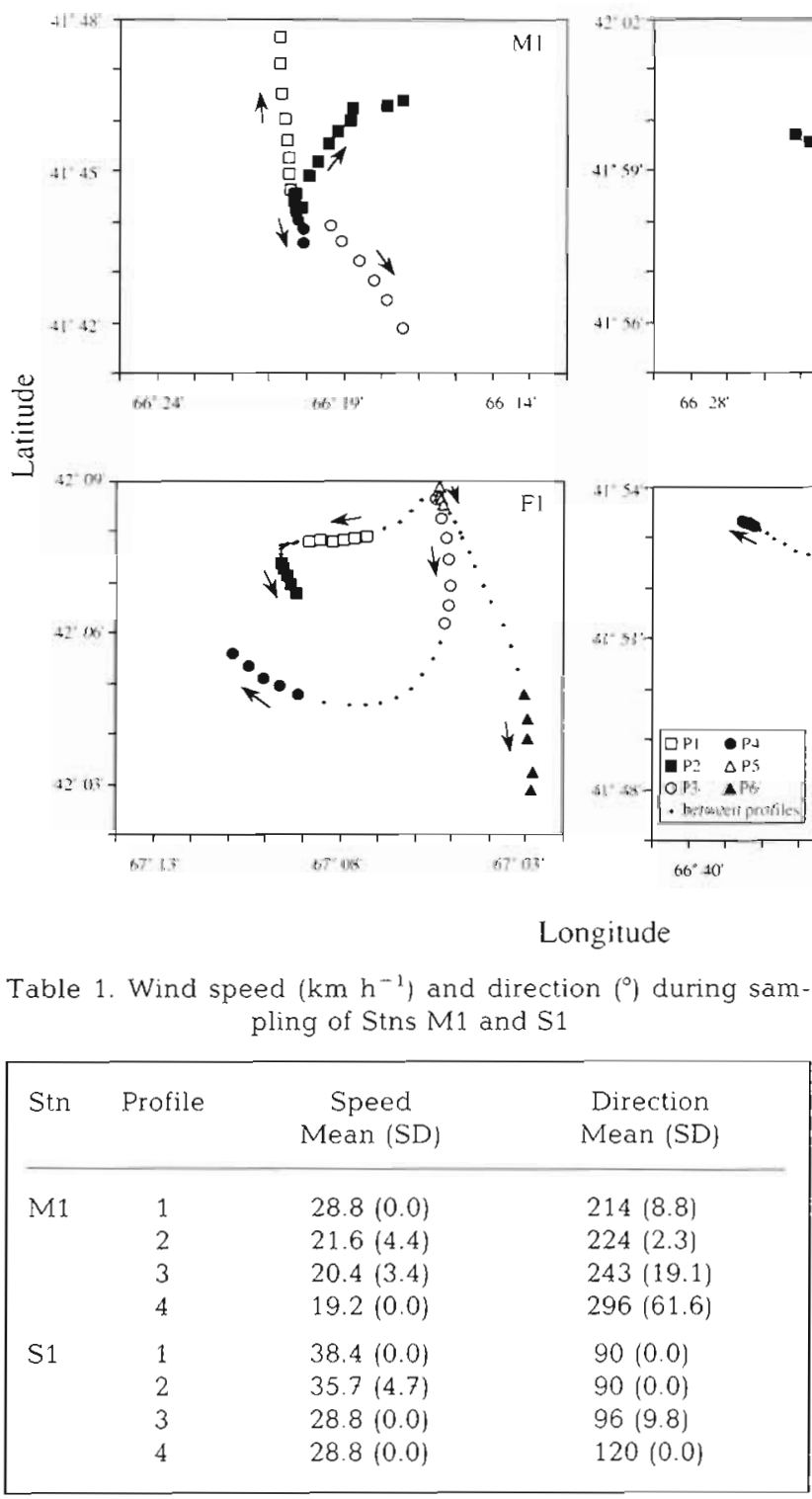

9) the pycnocline was absent or only weakly developed and the temperature difference between the surface and $50 \mathrm{~m}$ was often $<3^{\circ} \mathrm{C}$. Physical profiles at the mixed stations (Figs, 4, 7 and 10) were homogenous except for single profiles at each of $\mathrm{M} 2$ and M3 (Figs. 4 and 7) which were done in slightly stratified waters due to the ship drifting out of the well-mixed area.

\section{Chlorophyll a and particle profiles}

The concentration of chlorophyll $a<15 \mu \mathrm{m}$ comprised 61 to $88 \%$ of the total chlorophyll a (Table 2). Together with particle concentrations, chlorophyll a $<15$ um generally declined during October of 1987 (Table 2; Fig. 11) with the steepest declines occurring at the weakly stratified stations (Figs. $3,5,6,8$ and 11).
Fig. 2. Drift track while sampling 2 stations in 1986 (M1 and S1) and 2 stations in 1987 ( $F 1$ and $S 2 b$ ). Time separating symbols is $15 \mathrm{~min}$. In 1986, the ship returned to the plotted station location for the start of each profile. In 1987, 2 profiles were done before returning to the original location. Non-pumping periods are indicated for 1987 tracks. Times of profiles can be obtained from Figs. 5, 6, 9 and 10

The concentration of chlorophyll $a<15 \mu \mathrm{m}$ and the concentration of particles showed similar trends with depth (Fig. 11). Where the water column was well mixed, chlorophyll a and particles were generally evenly distributed over the whole water column (Figs. 4,7 and 11), while at stations with some stratification, these variables were usually most concentrated in the upper $10 \mathrm{~m}$, decreasing with depth (Figs. 3, 5, 6, 8 and 11). Ignoring profiles in mixed waters, only 5 of the 21 profiles had subsurface increases in chlorophyll a $<15 \mu \mathrm{m}$, and most of these increases were marginal (Figs. 3, 5 and 6). Subsurface increases in particle concentration were also small (Fig. 11).

\section{Density, aggregation and the ZCM of sea scallop larvae}

Depth-averaged concentrations of sea scallop larvae at the stratified stations were generally greater and more variable than at the mixed stations (Table 2 ). The mean concentration of larvae ranged from $16 \mathrm{~m}^{-3}$ at Stn M3 to $520 \mathrm{~m}^{-3}$ at Stn S2a, while the coefficient of variation (CV) among profiles ranged from $33 \%$ at $\mathrm{M} 3$ to $94 \%$ at Stn F1 (Table 2).

Sea scallop larvae were aggregated within subsurface depth intervals at stratified stations (Figs. 3, 5, 6, 8 and 9), and well mixed over the water column where stratification was low (Figs. 4,7 and 10). An index of the extent of aggregation for any given profile is the $\mathrm{CV}$ of the larval concentration over the different depth inter- 

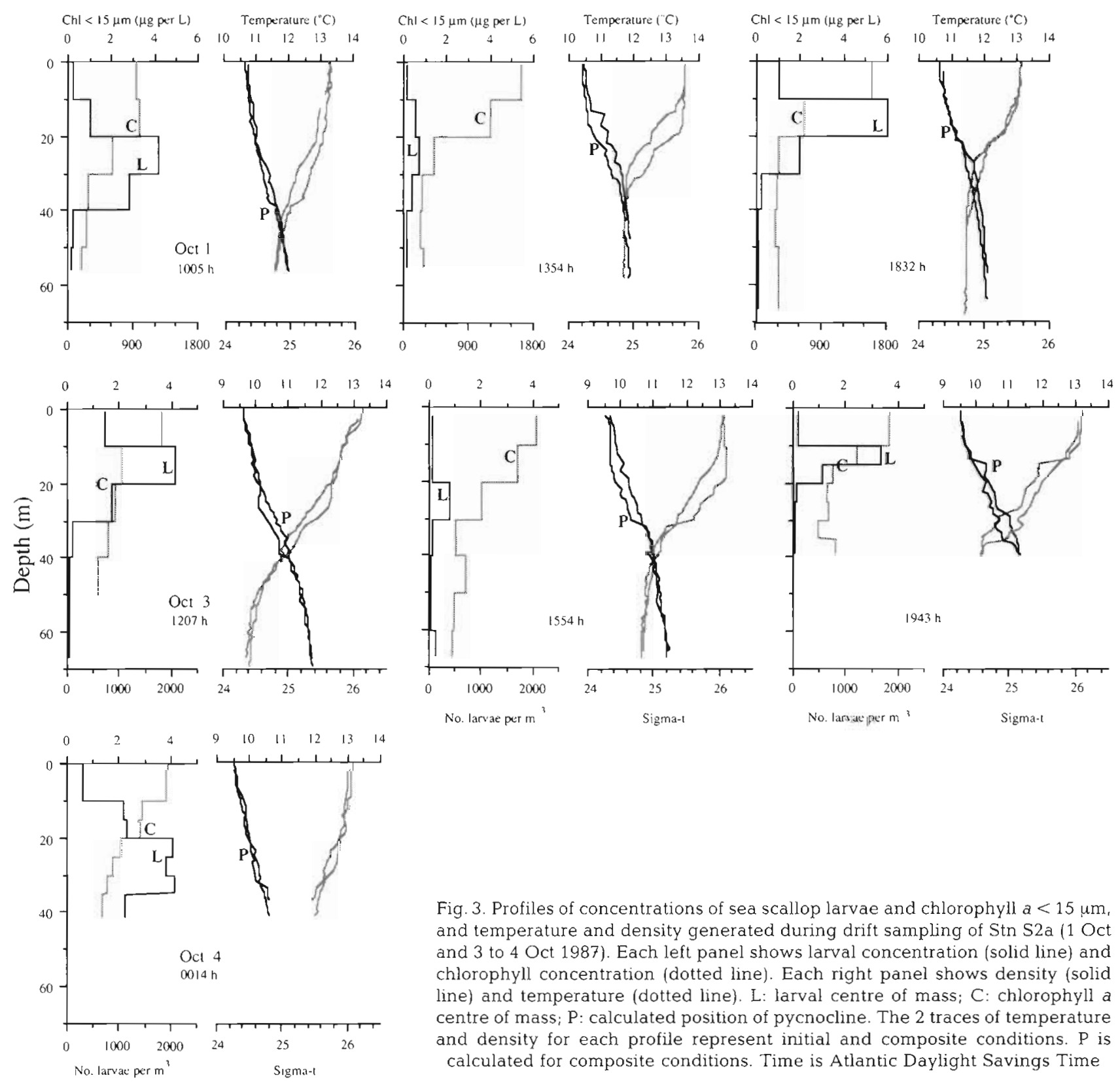

Table 2. Placopecten magellanicus. Concentrations of sea scallop larvae $\left(\mathrm{n} \mathrm{m}^{-3}\right)$ and chlorophyll a $<15 \mu \mathrm{m}\left(\mu \mathrm{g} \mathrm{l}^{-1}\right)$ averaged over the upper $50 \mathrm{~m}$ or to the maximum sampling depth. N: number of profiles upon which means are based; CV: coefficient of variation; PCT: concentration of chlorophyll $<15 \mu \mathrm{m}$ as a percentage of the total chlorophyll a from all size fractions (based on one profile done at each station except for S2a which is based on 3 profiles)

\begin{tabular}{|c|c|c|c|c|c|c|}
\hline Stn & Date & $\mathrm{N}$ profiles & Larvae & CV (larvae) & $\mathrm{Chl}$ & PCT \\
\hline M1 & 10 Oct 1986 & 4 & 19.6 & 38.7 & - & - \\
\hline S1 & 11 Oct 1986 & 4 & 120.8 & 37.5 & - & - \\
\hline S2a & $1-4$ Oct 1987 & 7 & 519.5 & 75.8 & 2.20 & 63 \\
\hline M2 & 6 Oct 1987 & 6 & 171.2 & 69.1 & 2.15 & 75 \\
\hline F1 & 12 Oct 1987 & 6 & 78.8 & 93.6 & 1.27 & 88 \\
\hline $\mathrm{S} 2 \mathrm{~b}$ & 14 Oct 1987 & 6 & 19.6 & 53.9 & 0.95 & 84 \\
\hline M3 & 15 Oct 1987 & 6 & 16.1 & 32.5 & 1.57 & 70 \\
\hline S3 & 18 Oct 1987 & 2 & 285.7 & 61.2 & 0.80 & 61 \\
\hline
\end{tabular}




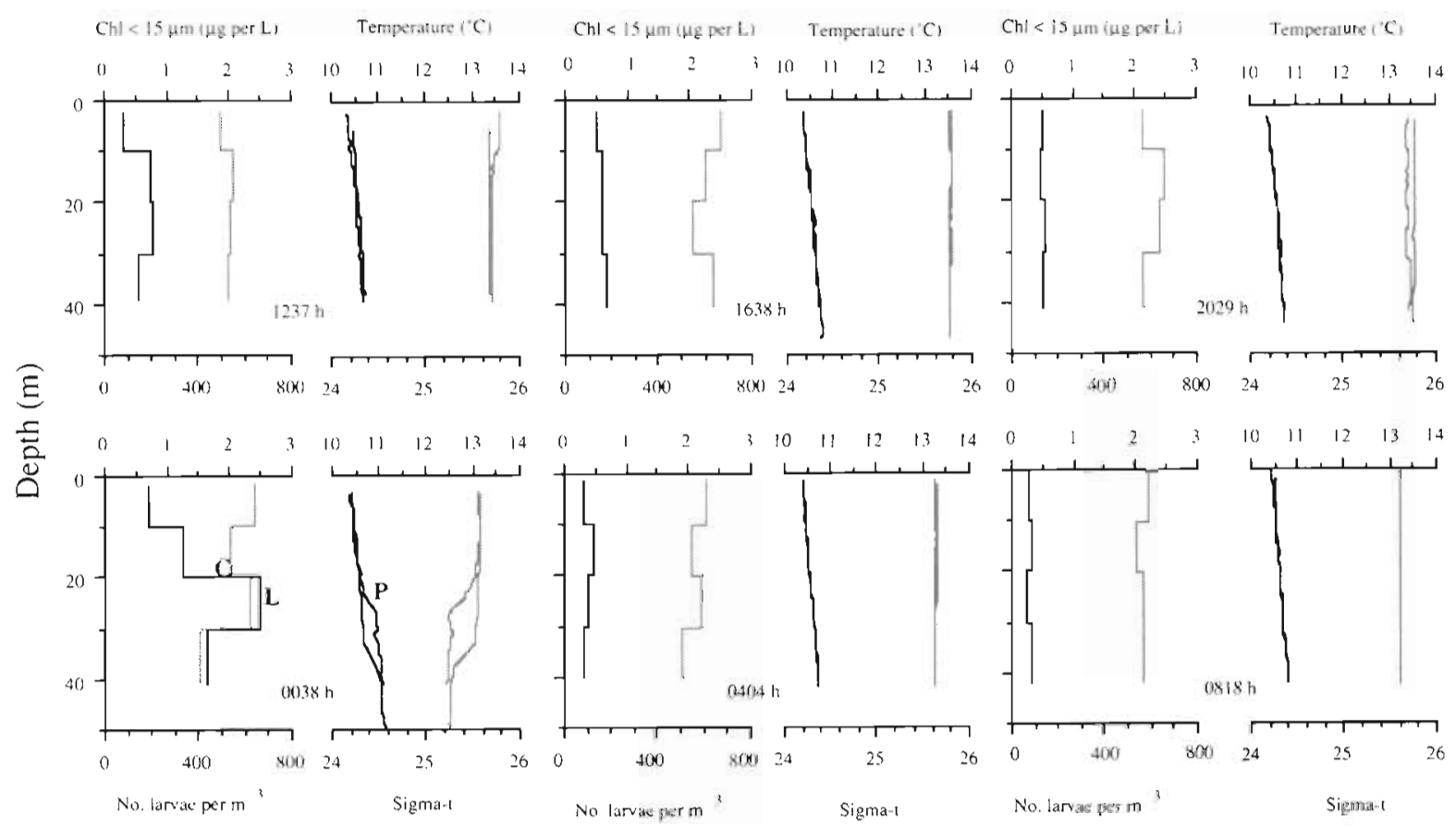

Fig. 4. Profiles of concentrations of sea scallop larvae and chlorophyll $a<15 \mu \mathrm{m}$, and temperature and density generated during drift sampling of Stn M2 (6 to 7 Oct 1987). See Fig. 3 caption

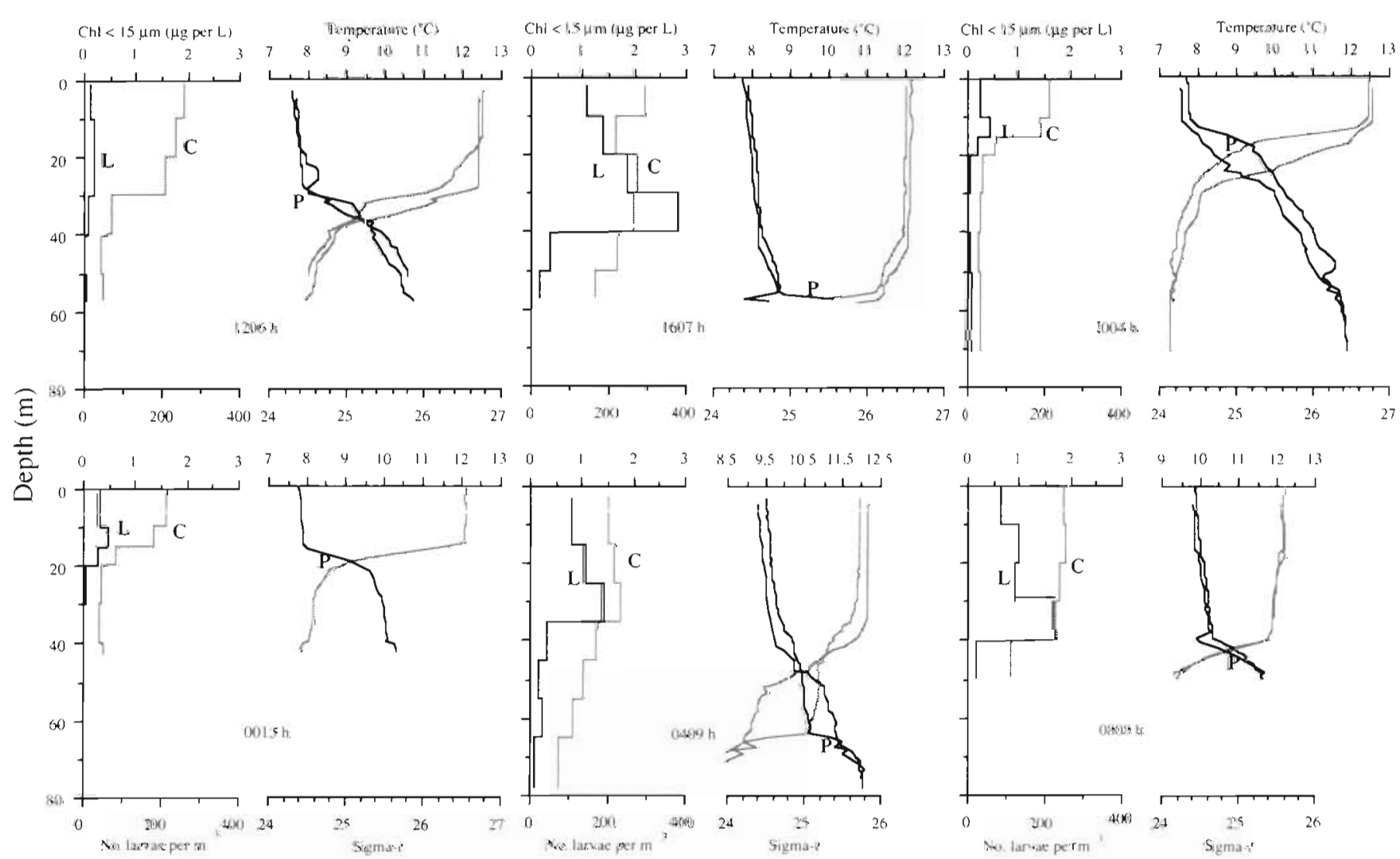

Fig. 5. Profiles of concentrations of sea scallop larvae and chlorophyll $a<15 \mu \mathrm{m}$, and temperature and density generated during drift sampling of Stn F1 (12 to 13 Oct 1987). Composite physical conditions are unavailable for the 00:15 h profile. See Fig 3 

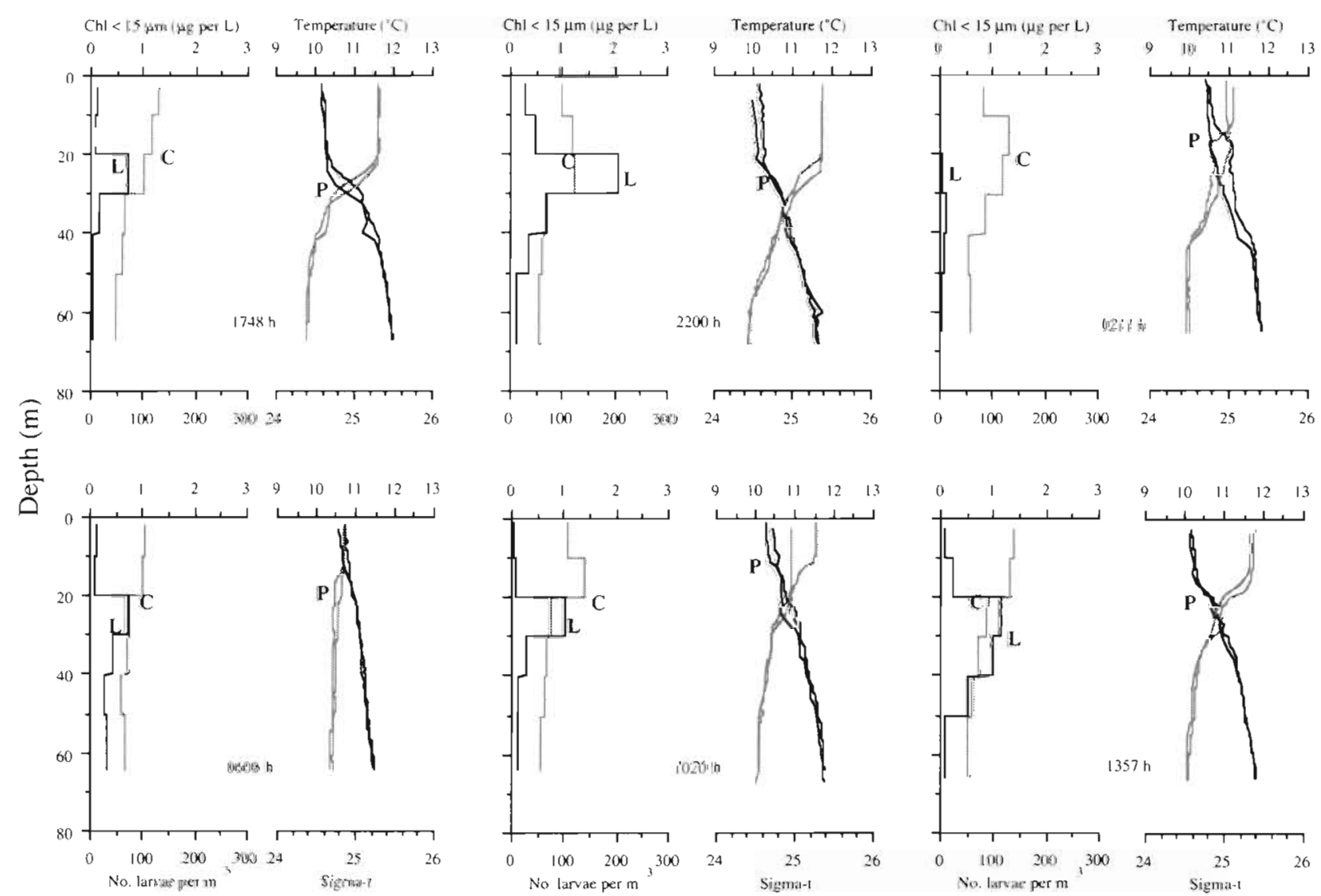

Fig. 6. Profiles of concentrations of sea scallop larvae and chlorophyll $a<15 \mu \mathrm{m}$, and temperature and density generated during drift sampling of Stn S2b (14 to 15 Oct 1987). See Fig. 3 caption

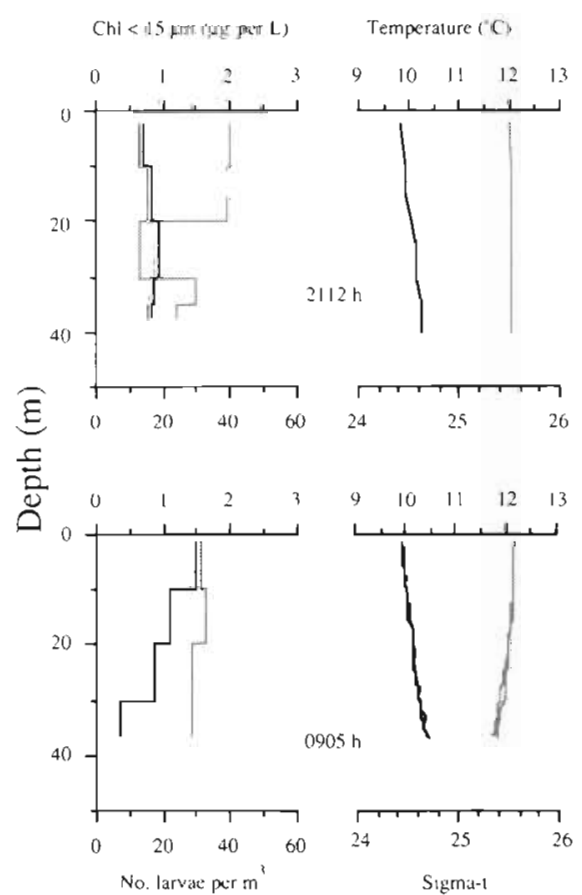

$\mathrm{Chl}<15 \mu \mathrm{m}(\mu \mathrm{g}$ Fer L $)$

Tempcrature ( $\mathrm{C}$ )

$\mathrm{Chl}<15 \mu \mathrm{m}(\mu \mathrm{g} \operatorname{per} \mathrm{L})$

Temperature ( $\mathrm{C}$ )
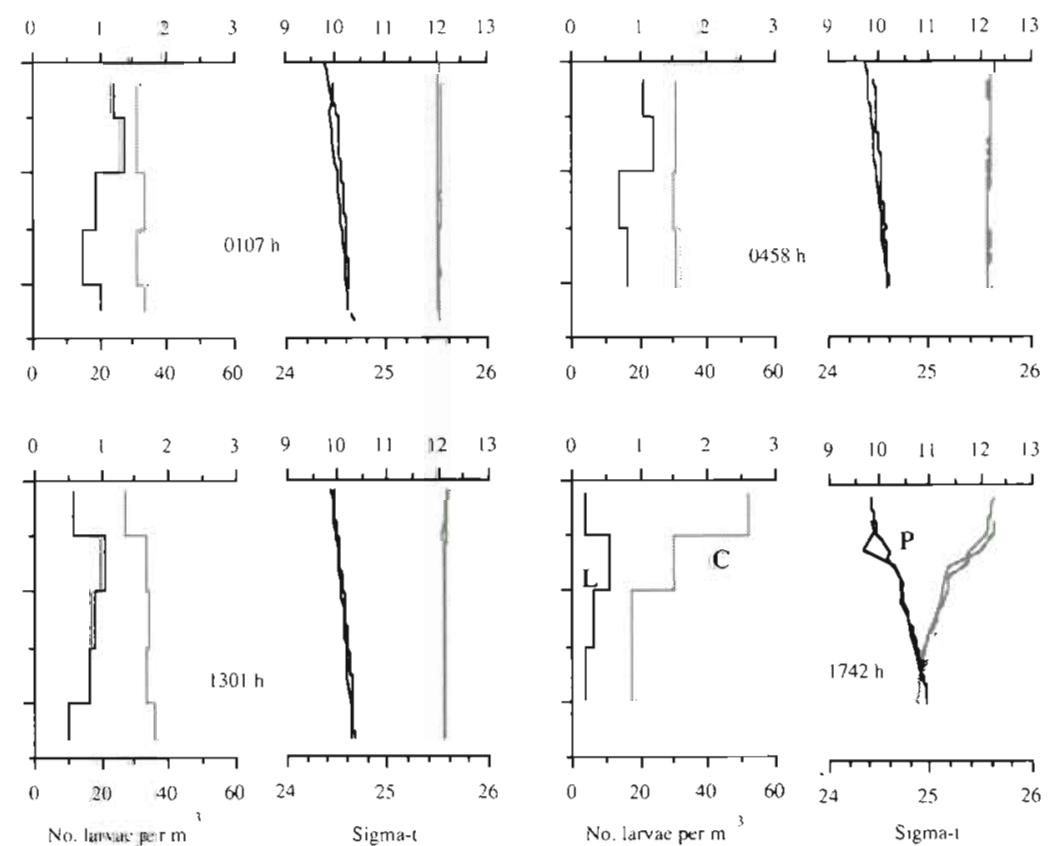

Fig. 7. Profiles of concentrations of sea scallop larvae and chlorophyll $a<15 \mu \mathrm{m}$, and temperature and density generated during drift sampling of Stn M3 (15 to 16 Oct 1987). See Fig. 3 caption 

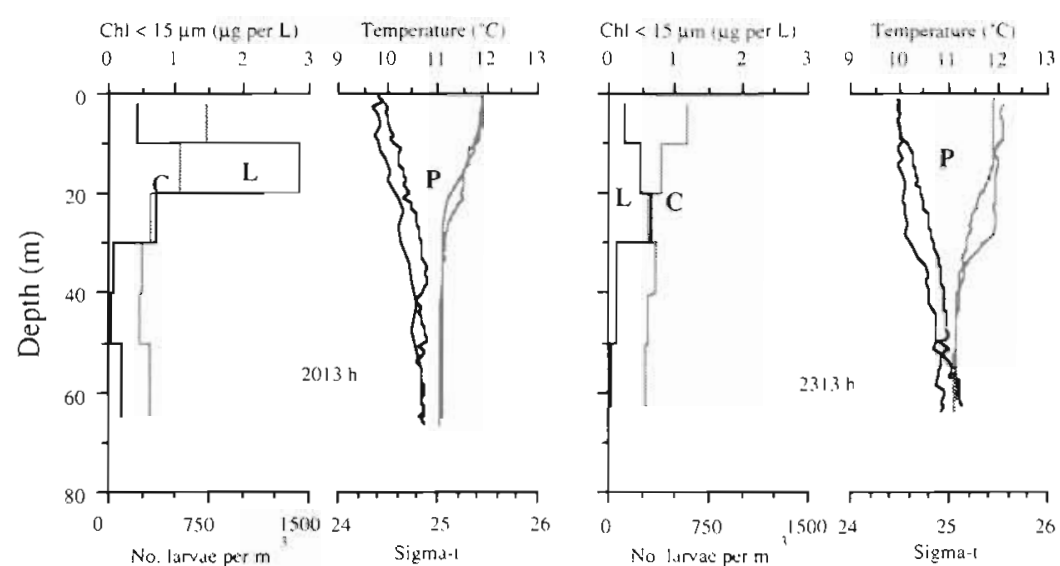

Fig. 8. Profiles of concentrations of sea scallop larvae and chlorophyll $a<15 \mu \mathrm{m}$, and temperature and density generated during drift sampling of Stn S3 (17 to 18 Oct 1987).

See Fig. 3 caption
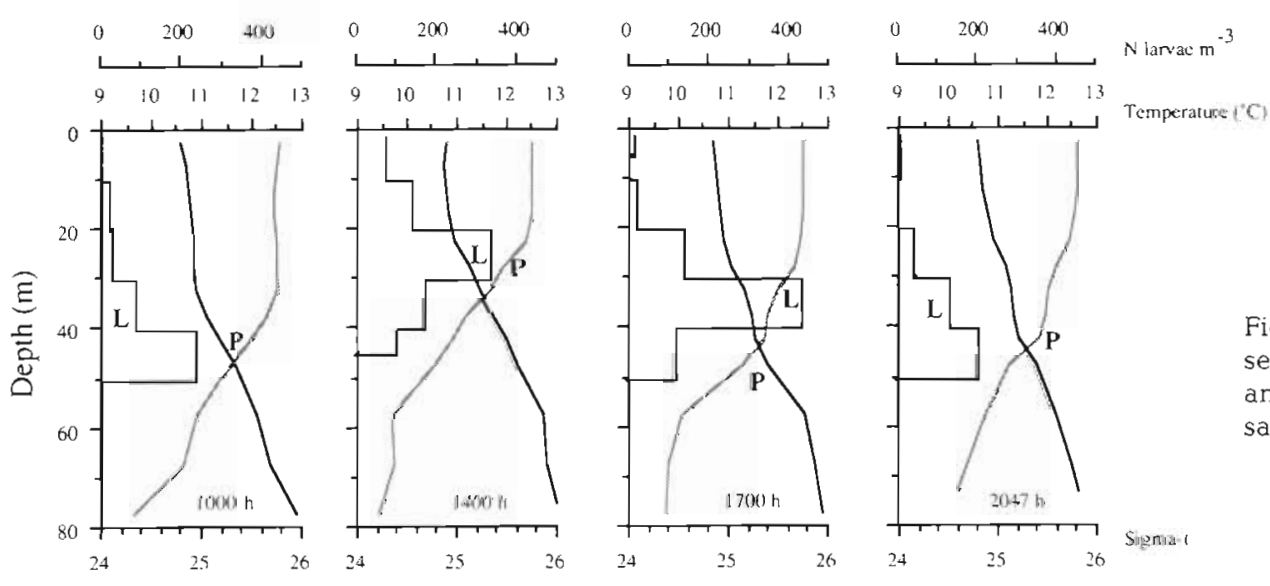

Fig. 9. Profiles of concentration of sea scallop larvae, temperature and density generated during drift sampling of Stn S1 (11 Oct 1986).

Solid stepped line is larval concentration, other solid line is density, dotted line is temperature
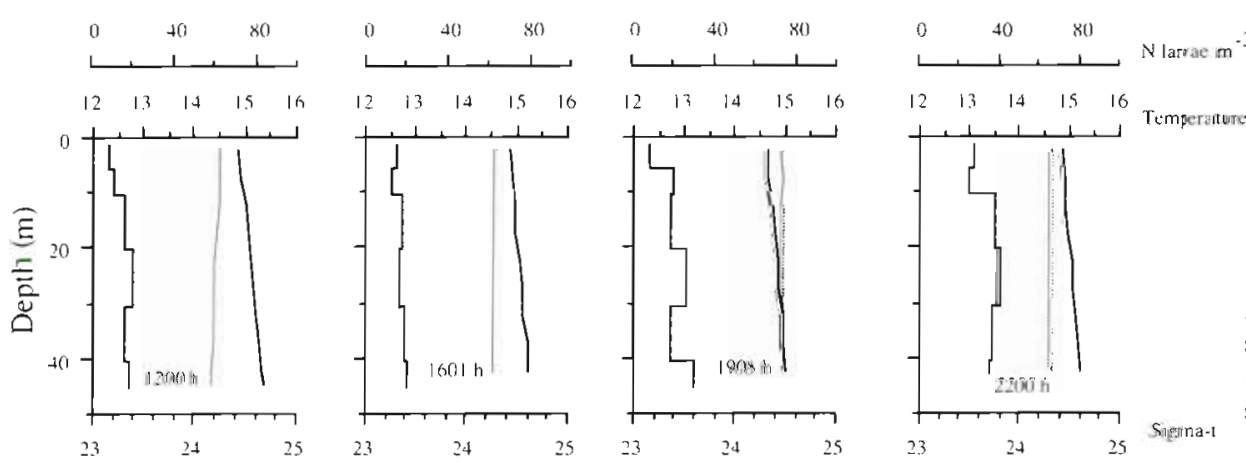

Fig. 10. Profiles of concentration of sea scallop larvae, temperature and density generated during drift sampling of Stn M1 (10 Oct 1986). See Fig. 9 caption

vals, i.e. a high aggregation generates a high CV This index increased with density stratification (S), and above $\mathrm{S}$ values of about 0.007 , larvae were aggregated at subsurface depths (Fig. 12). Chlorophyll a $<15$ um showed the same increased aggregation with stratification but was less aggregated than sea scallop larvae for any given value of $\mathrm{S}$ (Fig. 12) perhaps reflecting the lower mobility of the phytoplankton.

The ZCM of sea scallop larvae is meaningful only when the aggregation of larvae is substantial, defined here as when the $\mathrm{CV}$ is greater than $50 \%$. This eliminates most of the profiles from the mixed stations (Fig. 12). In the remaining 28 profiles, the larval ZCM

ranged from 11 to $38 \mathrm{~m}$ and was above or within $2 \mathrm{~m}$ of the pycnocline in 21 profiles. The larval ZCM was usually below both the depth interval where chlorophyll a $<15 \mu \mathrm{m}$ was most concentrated, and the corresponding chlorophyll ZCM (Figs. 3 to 8). In only one profile was there a coincidence between a subsurface increase in chlorophyll $a<15 \mu \mathrm{m}$ and the larval ZCM (Fig. 5). This was at the frontal station (F1), where the pycnocline was particularly strong, and the larval ZCM and the chlorophyll a ZCM covaried with the depth of the pycnocline (Fig. 5 ; Table 3). Where the pycnocline was shallow, sea scallop larvae were compressed into the region above it and the underlying 


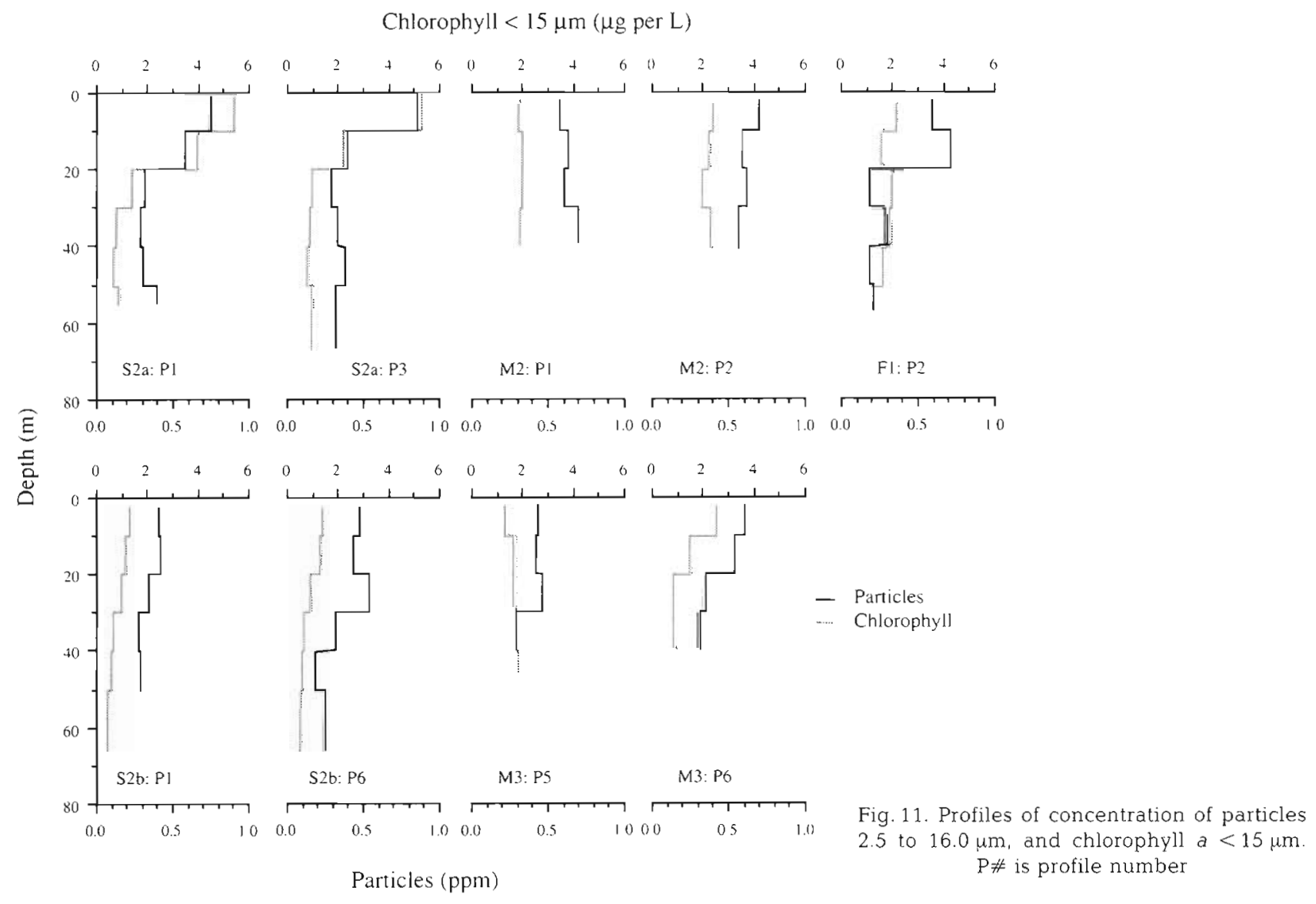

cold water mass (Fig. 5). For 2 of the other 3 stratified stations, the larval ZCM was positively related to the depth of the pycnocline, but the chlorophyll a ZCM was not clearly related to either the larval ZCM or the pycnocline depth (Table 3). Stn S2b was anomalous in that the ZCM was usually below the calculated pycnocline depth, perhaps due to the lower stratification at this station (Table 3 ).

Temperature at the larval ZCM was 10.4 to $12.8^{\circ} \mathrm{C}$ (mean $=11.9, \mathrm{SD}=0.70$ ) and $75 \%$ of the larvae for any profile were usually within a temperature range of $\pm 2{ }^{\circ} \mathrm{C}$ (Fig. 13). Larvae were found in the lowest temperatures at Stns S2b and S3, where temperatures above the weak pycnocline were lower than other stations (Figs. 6, 8 and 13).

\section{Diel differences in the ZCM and differences in larval length with depth}

There were no consistent day-night differences in the ZCM of larvae to suggest diel vertical migration. This was the case whether the data were examined within station (Figs. 3, 5, 6 and 10) or over all stations (Fig. 14; Table 4). Where the pycnocline was strong, variation in the pycnocline depth had more of an effect on the ZCM than the diel light cycle (Figs. 5 and 9). Size-dependent differences in vertical distribution were undetectable or unsystematic. The ZCMs of different sized larvae were not significantly different (Table 4), and a comparison of the length distribution of larvae at different depth intervals showed small differences at Stn S2, and no significant differences at Stn M1 (Table 5).

\section{DISCUSSION}

The drift of the ship during sampling was largely a function of the lunar semidiurnal tidal current on Georges Bank. On the Northeast Peak, this current swings in a clockwise direction though an ellipse every $12.4 \mathrm{~h}$. The ellipse is oriented northwest-southeast and has a major axis length of 12 to $15 \mathrm{~km}$ (Lough \& Trites 1989). The direction and distances drifted by the ship (Fig. 2) were close to those predicted from tide tables and tidal current speeds. Fortunately changes in water column structure during profiling were generally small, indicating that the ship drifted within relatively homogenous water masses. The ship was probably not an effective drogue of patches of sea scallop larvae however, since currents decrease with depth (Butman 


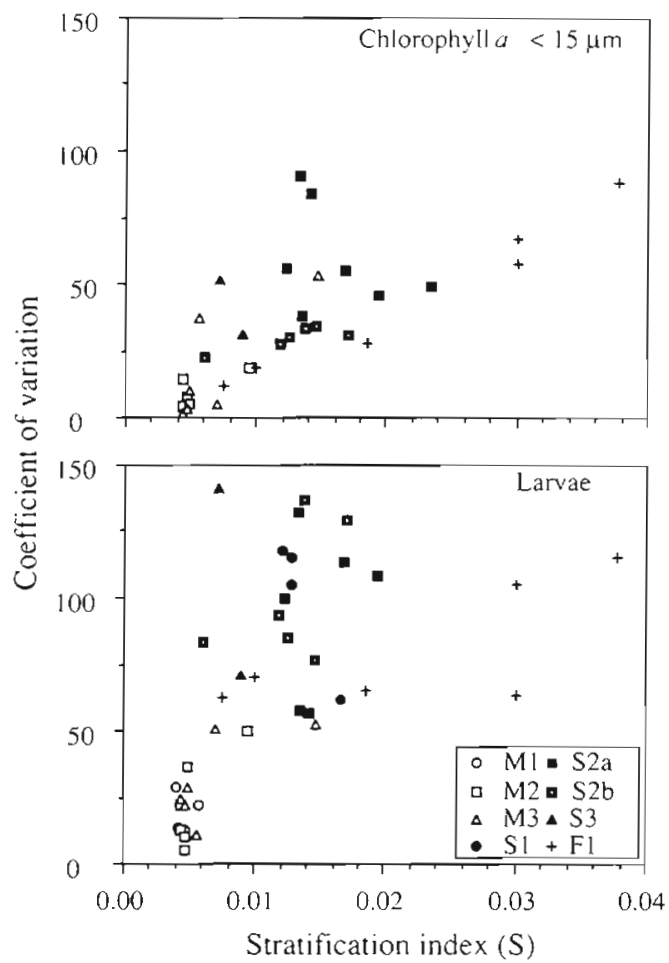

Fig. 12. Coefficient of variation versus stratification index (S) for chlorophyll $a<15 \mu \mathrm{m}$ and sea scallop larvae. Points from different stations are keyed by symbol (one point for each profile within a station)

Table 3. Placopecten magellanicus. Pearson correlation coefficients among ZCMs of sea scallop larvae and chlorophyll a $<15 \mu \mathrm{m}$, and the depth of the pycnocline. Only stations where larval aggregation is an important feature are included (see text). S; stratification index; LZCM: larval centre of mass; CZCM: chlorophyll a $<15 \mu \mathrm{m}$ centre of mass; P: pycnocline depth

\begin{tabular}{|lcccc|}
\hline Stn & S & LZCM \& P & LZCM \& CZCM & CZCM \& P \\
\hline S1 & 0.014 & 0.71 & - & - \\
S2a & 0.016 & 0.67 & 0.00 & 0.35 \\
F1 & 0.022 & 0.86 & 0.97 & 0.80 \\
S2b & 0.013 & -0.81 & 0.39 & 0.04 \\
\hline
\end{tabular}

et al. 1987, Lough \& Trites 1989) and the ZCM of sea scallop larvae was usually 10 to $30 \mathrm{~m}$ below the ship. This current shear may explain some of the patchiness indicated by the variance in larval concentration between profiles, and the fact that the CV of the average concentration of larvae was lower at the mixed stations (Table 2), where current shear is expected to be low.

The presence or absence of a subsurface aggregation of sea scallop larvae on Georges Bank is predictable from the density structure. When the stratification index (S) was less than about 0.007 , sea scallop larvae were distributed evenly over the whole water column, and can probably be con-sidered passive particles. As such, sea scallop larvae in the mixed areas of Georges Bank may be redistributed over the water column every 5 h (Loder et al. 1988), and their horizontal movement should be a function of the depth-averaged residual current. Above S values of 0.007 , sea scallop larvae were aggregated below the surface, in several cases above or within the pycnocline.

A specific objective of this study was to determine if sea scallop larvae aggregate in relation to increased concentrations of food. It is apparent that sea scallop larvae on Georges Bank do not aggregate in relation to the concentrations of chlorophyll a $<15 \mu \mathrm{m}$ or particles 2.5 to $16.0 \mu \mathrm{m}$. Subsurface increases in the concentrations of chlorophyll $a<15 \mu \mathrm{m}$ or particles were not prominent features, with most profiles showing the greatest concentration of phytoplankton and particles in the upper $10 \mathrm{~m}$, above the depth where sea scallop larvae were most concentrated. Even where a subsurface chlorophyll a maximum was present, the larval ZCM was below it in all but one profile. Although our sampling resolution (5 to $10 \mathrm{~m}$ ) was not sufficient to detect small spikes in chlorophyll a less than $5 \mathrm{~m}$ in width, it was sufficient to detect subsurface chlorophyll maxima typical of the Gulf of Maine region. In this area chlorophyll a concentrations within subsurface maxima are typically 1 to 5 times the background levels, and are 10 to $15 \mathrm{~m}$ in width (Sameoto 1984, Townsend et al. 1984).

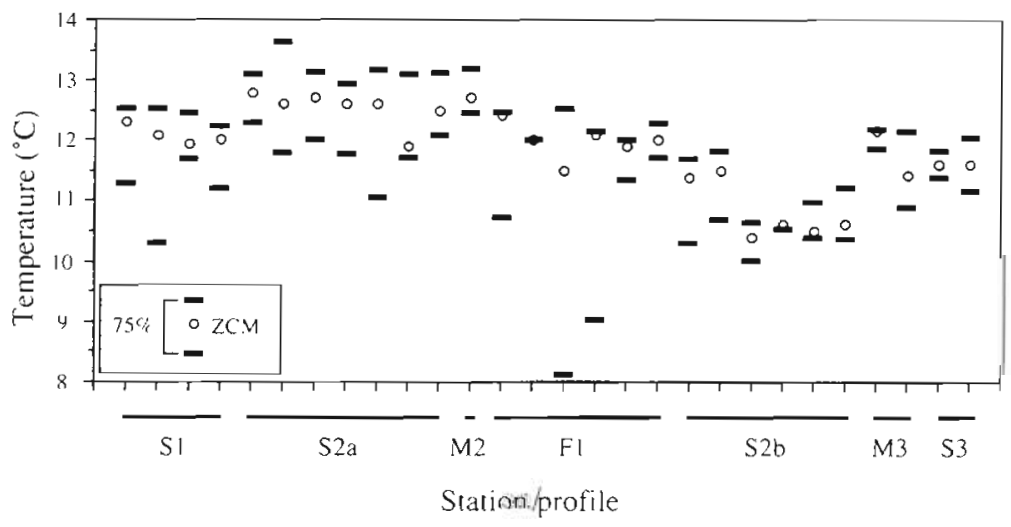

Fig. 13. Temperature at ZCM and range over which most larvae were found. Range corresponds to temperatures at depths equidistant from ZCM, between which $75 \%$ of larvae were found 
A number of factors can give rise to the formation of subsurface chlorophyll a maxima (Cullen \& Eppley 1981, Cullen 1982) but a sufficiently developed pycnocline may be required for their formation in the Gulf of Maine area (Townsend et al. 1984) and in other tidally dominated seas (Pingree et al. 1976). On Georges Bank the month of October is a period of transition to the more vertically mixed waters of late autumn and winter, and subsurface chlorophyll maxima are not a regular feature (Sameoto 1984, O'Reilly et al. 1987). In September the water is more consistently stratified and

Table 4. Placopecten magellanicus. ZCMs (m) of larvae within different size classes summarized for profiles completed during daylight (08:00 to $18: 30 \mathrm{~h})$ and darkness (21:00 to 05:00 h). Not included were profiles done where CV of larval aggregation $<50 \%$, and profiles done near dawn or dusk. $N$ : number of profiles. Analysis of variance indicated that neither size class nor time of day had a significant effect on the ZCM $(p>0.4)$

\begin{tabular}{|c|c|c|c|c|}
\hline \multirow[t]{2}{*}{ Time of day } & \multirow[t]{2}{*}{$N$} & \multicolumn{3}{|c|}{ Length $(\mu \mathrm{m})$} \\
\hline & & $<133$ & $133-201$ & $>201$ \\
\hline Daylight & 15 & 23.9 & 24.9 & 24.8 \\
\hline Darkness & 7 & 25.5 & 23.7 & 22.7 \\
\hline
\end{tabular}

subsurface chlorophyll maxima are more prevalent (O'Reilly et al. 1987).

Our measurements of chlorophyll a (Table 2) are somewhat higher than those made previously on Georges Bank at this time of year. Water column averages of chlorophyll a in the nannoplankton $(<20 \mu \mathrm{m})$ during October averaged over $6 \mathrm{yr}$ are ca $0.6 \mu \mathrm{gl}^{-1}$ in the weakly stratified area, and $0.9 \mu \mathrm{g} \mathrm{l}^{-1}$ in the well-mixed area (O'Reilly et al. 1987). The high concentrations of chlorophyll a observed at Stn S2a in early October (Table 2; Fig. 3) must represent a temporary, perhaps anomalous situation. The close relationship between particles and chlorophyll a for these profiles (Fig. 11) suggests that the particle field was dominated by living phytoplankters

Given that sea scallop larvae feed on phytoplankters less than 10 to $15 \mu \mathrm{m}$, the percentage of the total phytoplankton within this size range may be a factor in its availability to sea scallop larvae. Areas of Georges Bank have previously been distinguished on the basis of the percentage of chlorophyll a which is contained in the nannoplankton $(<20 \mu \mathrm{m})$ (O'Reilly et al. 1987). During October, the central mixed region generally has the lowest percentage (30 to $50 \%$ ) while the stratified region at the edge of Georges Bank has the highest percentage of nannoplankton (O'Reilly et al. 1987). The
Fig. 14. ZCM of sea scallop larvae versus time of day for all profiles where larval aggregation important. Black bar delimits profiles obtained during darkness. Also depicted is location of pycnocline

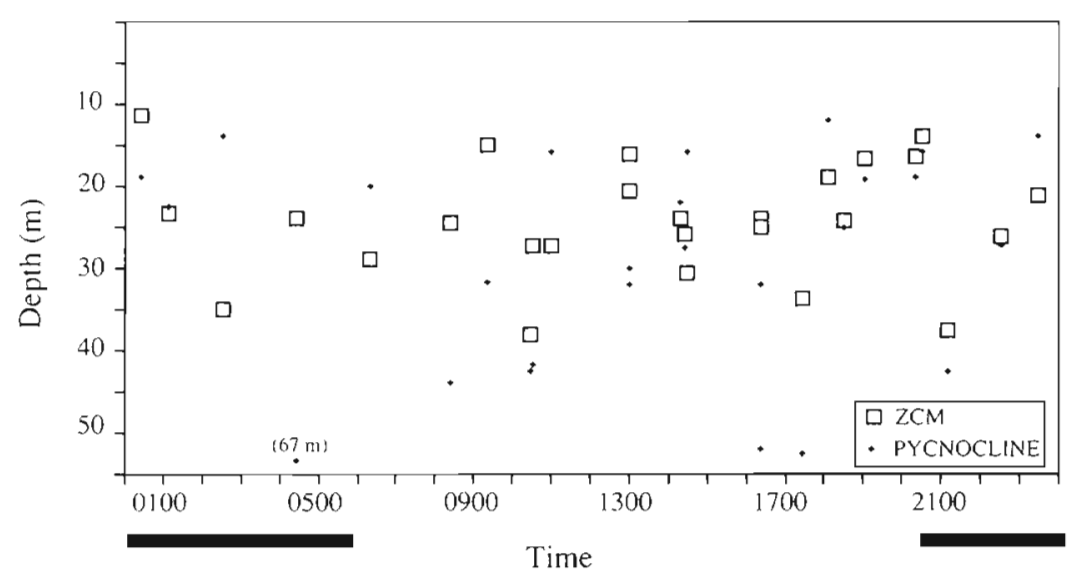

Time

Table 5. Placopecten magellanicus. Mean lengths of sea scallop larvae within different depth intervals for stratified (S1) and mixed (M1) stations in 1986. For comparison of lengths at different depths within stations, a Kruskal-Wallis analysis of variance by ranks was performed. Depth intervals with length distributions which are significantly different (Mann-Whitney comparisons, $\mathrm{p}<0.05)$ are indicated by different superscripted letters. Mean number of larvae measured per depth interval was 98 for $\mathrm{S} 1(\mathrm{SD}=$ $48.1)$ and 60 for $M 1(S D=23.8)$. P: profile

\begin{tabular}{|c|c|c|c|c|c|c|c|c|}
\hline \multirow[t]{2}{*}{ Depth $(\mathrm{m})$} & \multicolumn{4}{|c|}{ Stratified } & \multicolumn{4}{|c|}{ Mixed } \\
\hline & $\mathrm{P} 1$ & $\mathrm{P} 2$ & P3 & P4 & P1 & P2 & P3 & P4 \\
\hline $0-5$ & $157^{\mathrm{a}}$ & $155^{\mathrm{ab}}$ & 156 & $152^{\mathrm{ab}}$ & 138 & 141 & 141 & 141 \\
\hline $6-10$ & $160^{\circ}$ & $152^{d}$ & 165 & $153^{a b}$ & 134 & 146 & 136 & 139 \\
\hline $11-20$ & $162^{4}$ & $158^{b c}$ & 157 & $157^{\text {ab }}$ & 136 & 139 & 137 & 140 \\
\hline $21-30$ & $162^{\mathrm{a}}$ & $162^{c}$ & 159 & $150^{a}$ & 144 & 142 & 139 & 138 \\
\hline $31-40$ & $170^{b}$ & $160^{c}$ & 158 & $158^{\mathrm{l}}$ & 146 & 144 & 137 & 137 \\
\hline $41-50$ & $159^{\circ}$ & $161^{c}$ & 160 & $151^{\mathrm{d}}$ & 139 & 138 & 139 & 139 \\
\hline
\end{tabular}


8 profiles for which total chlorophyll a was measured together with the $<15$ um fraction in the present study only partially substantiate this generalization. The most stratified station (F1), had the highest percentage nannoplankton ( $88 \%$ ), but the mixed station did not have the lowest percentage (Table 2).

Profiles of production by food organisms consumed by sea scallop larvae may differ from the profiles of food concentration (Figs. 3 to 8 and 11). Picoplankton $(<3 \mu \mathrm{m})$, which may be a significant source of food for sea scallop larvae, comprises a greater fraction of the total primary production at subsurface depths than at the surface, due to more efficient utilization of low light intensities and green light than larger phytoplankters (Glover et al. 1985, Waterbury et al. 1986). Further study is required to determine the importance of picoplankton to the nutrition of sea scallop larvae, and whether there is an increase in picoplankton production in subsurface layers where sea scallop larvae aggregate.

The location of the pycnocline is an important feature in determining the vertical distribution of sea scallop larvae on Georges Bank. Where it is well developed, it coincides with the lower limit of occurrence of larvae (Fig. 5), and its fluctuations are associated with fluctuations in the larval ZCM. The depth of the pycnocline on the Northern Flank of Georges Bank varies with location and tidal stage (see Fig. 12 of Lough \& Trites 1989) and the differences in pycnocline depth between profiles at Stn F1 could have resulted from ship drift, changes in the tidal current, or a combination thereof. Whether individual sea scallop larvae actually undergo the shifts in vertical position suggested by the changes in the ZCM between profiles at Stn F1 (Fig. 5) cannot be determined from the present study.

Short-term variation in the ZCM of sea scallop larvae may be affected by the action of internal waves, which propagate onto the Northern Flank with the tidal current ( $J$ Loder, Bedford Institute of Oceanography, pers. comm.). Tidally driven internal waves can cause vertical oscillations of the pycnocline of up to $30 \mathrm{~m}$ for 1 to $2 \mathrm{~h}$ of every tidal cycle in the Gulf of Maine (Haury et al. 1983), and zooplankton and phytoplankton can be transported with such oscillations (Haury 1976. Haury et al. 1978, Hargreaves 1981, Haury et al. 1983, Le Fevre 1986). In the present study, internal. waves were not a dominant feature during profiling (Figs. 3 to 8), although internal waves may have passed during Profiles 3 and 5 at Stn F1 (Fig. 5). The ship was at its most northerly extent during these profiles, and the tidal current was flowing onto the bank (Fig. 2), conditions which suggest the presence of internal waves.

Evidence that swimming behavior of sea scallop larvae was important in regulating their vertical distribution was absent from the present study. In the mixed parts of Georges Bank, the larvae appear to act as passive particles. In areas with density stratification, the role of behavior is less certain, but short-term changes in the depth of the pycnocline will likely overwhelm directed movement by sea scallop Iarvae. The lack of a diel difference in the larval Z.CM, and the fact that differences in larval size with depth were not systematic supports this view. Scallop larvae do respond to light (Kaartvedt et al. 1987, Silva \& O'Dor 1988 ) and pressure (Cragg 1980), but are less pressuresensitive than estuarine species (Cragg 1980, Mann \& Wolf 1983). Small differences in depth distribution $(<5$ to $10 \mathrm{~m}$ ) over time or with size would not have been detected with the sampling resolution of the present study, but changes of this magnitude are likely to be secondary to short-term changes in water column structure.

The temperature range $\left(10\right.$ to $\left.13.5^{\circ} \mathrm{C}\right)$ over which sea scallop larvae were usually found coincides with the temperatures found in the upper mixed layer, and whether temperature, or some other stimulus, caused the larvae to swim above the pycnocline is an open question. Sea scallop larvae are successfully grown in hatcheries at temperatures of 12 to $15^{\circ} \mathrm{C}$, but more systematic study is required to establish the optimum temperature (Tremblay 1988).

Although larval swimming behavior may be insignificant in determining short-term variations in vertical distribution, the formation of subsurface aggregations above or within the pycnocline may well result from an interaction between behavior and water column turbulence. In the laboratory, sea scallop larvae often swarm, and if this tendency is present in nature, the subsurface aggregations may reflect such swarms. Low turbulence may be necessary for the low swimming speeds of larvae $\left(<1.7 \mathrm{~mm} \mathrm{~s}^{-1}\right.$; Silva \& O'Dor 1988) to be effective in forming swarms, and turbulence is expected to decline in the region of the pycnocline (Sunby 1989). Other bivalve larvae are also associated with the pycnocline (or thermocline) but the associations have been explained either in terms of temperature or food. Mann (1986) argued that the restriction of Arctica islandica larvae to depths of 20 to $40 \mathrm{~m}$ during September was due to active avoidance of warm surface water, but since these larvae were most aggregated in the region of the thermocline at that time, an association with decreased turbulence cannot be ruled out. Similarly Scrope-Howe \& Jones (1986) found that bivalve larvae were associated with a subsurface chlorophyll a maximum, but since this was associated with the thermocline, decreased turbulence may have been important in the formation of the larval aggregations. To test the hypothesis that subsurface aggregations of bivalve larvae occur where turbulence is low, profiles 
of the velocity of turbulence (Rothschild \& Osborn 1988) are necessary. If there is an association, swimming speeds of bivalve larvae can then be compared with the turbulent velocity profiles to assess whether active swimming plays a role in the formation of the subsurface aggregations.

Active movement by sea scallop larvae must play a small role in depth regulation relative to larger, more mobile zooplankters. Using similar sampling resolution at the same time of year, several studies show that some zooplankters undertake extensive diel vertical migrations, or have size-dependent vertical distributions. These include some larval fish, chaetognaths, and some copepods (Lough 1976, Sameoto 1984, Lough \& Trites 1989). Other zooplankters are similar to sea scallop larvae and do not show diel differences in depth on Georges Bank at this time of year (Turner \& Dagg 1983, Sameoto 1984).

In areas where vertical shear is important, the horizontal movement of planktonic organisms will be affected by (1) the mean position of the plankters in the water column and (2) the extent and the period of vertical migration which occurs. Although previous authors have suggested that scallop larvae in nature are near the surface (Posgay 1979, Cragg 1980), this is clearly not the case for Georges Bank or the Bay of Fundy (Tremblay \& Sinclair 1988), and therefore surface currents alone will be inadequate for predicting horizontal movement of sea scallop larvae.

Modelling the horizontal movement of plankton via currents is more complex if the plankter vertically migrates, because of the interaction between vertical current shear and the vertical migration (Wroblewski 1982, Rothlisberg et al. 1983, Lough \& Trites 1989). For periods of less than $2 \mathrm{wk}$ the horizontal displacement of actively migrating (up to $60 \mathrm{~m}$ daily) adult chaetognaths on Georges Bank is much different than that predicted for non-migrating drifters (Lough \& Trites 1989). For periods greater than $2 \mathrm{wk}$ the situation is different because the daily $50 \mathrm{~min}$ shift in the tidal current has an averaging effect, and the horizontal displacement of chaetognaths is reduced by only $30 \%$ over non-migrators. To be effective in either retarding or enhancing horizontal movement over several weeks, vertical migrations must be on a tidal frequency rather than a diel frequency (Lough \& Trites 1989). Sea scallop larvae may undertake a small amplitude vertical migration $(<10 \mathrm{~m}$ ) on Georges Bank, but the frequency of the migration is most likely to be diel (Tremblay \& Sinclair unpubl.). Therefore modelling the horizontal movement of sea scallop larvae from circulation models of Georges Bank should be simpler than for larger plankters which undertake extensive vertical migrations.
Acknowledgements. We thank Captain N. Barnes and the crew of the research vessel 'Lady Hammond', and S. Wilson, P. Cranford, R. Duggan, D. Meade, J. Muelbert, A. Orr, S. Rao, D. Reimer, D. Roddick, R. Semple, and A. Silva, for valuable advice and assistance during the cruises. P. Vass loaned equipment, constructed the frame for the pump and CTD, and gave advice on sampling technique throughout the study. J. Reid was also generous with advice and equipment. S. Wilson and $\mathrm{D}$. Meade analysed most of the plankton samples, and helped with gear maintenance. J. Loder and S. Sumby are thanked for their patient explanations of some physical processes. The manuscript benefited from comments by R. Miller, S. Rao, G. Robert, S. Wilson and R. Mann.

\section{LITERATURE CITED}

Anderson, G. C., Frost B. W., Peterson, W. K. (1972). On the vertical distribution of zooplankton in relation to chlorophyll concentration. In: Takenouti, A. Y. (ed.) Biological oceanography of the northern North Pacific. Idemitsu Shoten, Tokyo, p. 341-345

Andrews, J. D. (1983). Transport of bivalve larvae in James River, Virginia. J. Shellfish Res. 3: 29-40

Bayne, B. L. (1983). Physiological ecology of marine molluscan larvae. In: Verdonk, N. H., Van den Biggelaar, J. A. M., Tompa, A. S. (eds.) The Mollusca, Vol. 3. Development. Academic Press, New York, p. 299-343

Bird, J. L. (1983). Relationships between particle-grazing zooplankton and vertical phytoplankton distributions on the Texas Continental Shelf Estuar coast. Shelf Sci. 16: $131-144$

Boicourt, W. C. (1982). Estuarine larval retention mechanisms on two scales. In: Kennedy, V. S. (ed.) Estuarine comparisons. Academic Press, New York, p. 445-457

Butman, B., Loder, J. S., Beardsley, R. C. (1987). The seasonal mean circulation: observation and theory. In: Backus, R. H., Bourne, D. W (eds.) Georges Bank. MIT Press, Cambridge, Massachusetts, p. 125-138

Carriker, M. R. (1951). Ecological observations on the distribution of oyster larvae in New Jersey estuaries. Ecol. Monogr 21: 19-38

Carriker, M. R. (1986). Influence of suspended particles on biology of oyster larvae in estuaries. Am. Mal. Union Spec Ed. No. 3: $41-49$

Cragg, S. M. (1980). Swimming behavior of the larvae of Pecten maximus (L.) (Bivalvia). J. mar. biol. Ass, U. K. 60: $551-564$

Cullen, J. J. (1982). The deep chlorophyll maximum: comparing vertical profiles of chlorophyll a. Can. J. Fish. Aquat. Sci. 39: 791-803

Cullen, J. J., Eppley, R. W. (1981). Chlorophyll maximum layers of the Southern California Bight and possible mechanisms of their formation and significance. Oceanologica Acta 4: 23-32

Culliney, J. L. (1974). Larval development of the giant sea scallop Placopecten magellanicus (Gmelin). Biol. Bull. mar. biol. Lab., Woods Hole $147 \cdot 321-332$

Drinnan, R. E., Stallworthy, W. B. (1979). Oyster larval populations and assessment of spatfall, Bideford River, P. E. I., 1959. Can. Fish. Mar. Serv. Tech. Rept. No.793. iii +16 p

Flagg, C. N. (1987). Hydrographic structure and variability. In: Backus, R. H., Bourne D. W. (eds.) Georges Bank. MIT Press, Cambridge, Massachusetts, p. 108-124

Fortier, L., Leggett, W. C. (1982). Fickian transport and the dispersal of fish larvae in estuaries. Can. J. Fish. Aquat. Sci. 39: 1150-1163 
Glover, H. E., Phinney. D. A., Yentsch, C. S. (1985). Photosynthetic characteristics of picoplankton compared with those of larger phytoplankton populations, in various water masses in the Gulf of Maine. Biol. Oceanogr. 3: $223-248$

Harding, G. C., Vass, W P., Hargrave B. T., Pearre, S., Jr (1986). Diel vertical movements and feeding activity of zooplankton in St. Georges Bay, N. S., using net tows and a newly developed passive trap. Can. J. Fish. Aquat. Sci. 43: 952-967

Hargreaves, N. B. (1981). Sub-surface chlorophyll maxima off Nova Scotia: relation to environmental parameters and zooplankton distributions. Ph. D. thesis, Dalhousie University

Harris, R. P., Fortier, L., Young, R. K. (1986). A large-volume pump system for studies of the vertical distribution of fish larvae under open sea conditions. J. mar biol. Ass. U.K. 66: 845-854

Haury, L. R. (1976). Small-scale pattern of a California Current zooplankton assemblage. Mar. Biol. 37: 137-157

Haury, L. R., McGowan, J. A., Wiebe, P. H. (1978). Patterns and processes in the time-space scales of plankton distributions. In: Steele, J. H. (ed.) Spatial pattern in plankton communities. Plenum, New York, p. 277-327

Haury, L. R., Wiebe, P. H., Orr, M. H., Briscoe, M. G. (1983) Tidally generated high-frequency internal wave packets and their effects on plankton in Massachusetts Bay. J. mar Res. 41: 65-112

Holm-Hansen, O., Lorenzen, C. J., Holmes, R. W., Strickland J. D. H. (1965). Fluorometric determination of chlorophyll J. Cons. Int. Explor. Mer. 30: 3-15

Kaartvedt, S., Aksnes, D. L., Egge, J. K (1987). Effect of light on the vertical distribution of Pecten maximus larvae. Mar Ecol. Prog. Ser. 40: 195-197

Korringa, P. (1952). Recent advances in oyster biology. Q. Rev. Biol. 27: 266-308

Kunkle, D. E. (1958). The vertical distribution of oyster larvae in Delaware Bay. Proc natn. Shellfish. Ass. 48: 90-91

LeFevre, J. (1986). Aspects of the biology of frontal systems. Adv. mar. Biol. 23: 163-299

Loder, J. W., Ross, C. K., Smith, P. C. (1988). A space- and timescale characterization of circulation and mixing over submarine banks, with application to the northwestern Atlantic continental shelf. Can. J. Fish. Aquat. Sci. 45: 1860-1885

Longhurst, A. R., Herman, A. W. (1981). Do oceanic zooplankton aggregate at, or near, the deep chiorophyll maximum? J. mar. Res. 39: 353-356

Loosanoff, $V$ L., Davis, H. C. (1963). Rearing of bivalve mollusks. Adv. mar. Biol. 1: 1-136

Lough, R. G. (1976). A preliminary report of the vertical distribution of herring larvae on Georges Bank. International Commission for Northwest Atlantic Fisheries (ICNAF) Res. Doc. 75/50. Ser. No. 3529

Lough, R. G., Trites, R. W. (1989). Chaetognaths and oceanography on Georges Bank. J. mar. Res. 47 343-369

Manahan, D. T., Crisp, D. J. (1982). The role of dissolved organic material in the nutrition of pelagic larvae: amino acid uptake by bivalve veligers. Am. Zool. 22: 635-646

Mann, R. (1985). Seasonal changes in the depth-distribution of bivalve larvae on the southern New England Shelf. J. Shellfish Res. 5: 57-64

Mann, R. (1986). Arctica islandica (Linne) larvae: active depth regulators or passive particles. Am. Mal. Unjon Spec. Ed. No. 3: $51-57$

Mann, R. (1988a). Distribution of bivalve larvae at a frontal system in the James River, Virginia. Mar Ecol. Prog. Ser. 50: $29-44$

Mann, R. (1988b). Field studies of bivalve larvae and their recruitment to the benthos: a commentary. J. Shellfish Res 7: $7-10$

Mann, R., Wolf, C. C. (1983). Swimming behavior of larvae of the ocean quahog Arctica islandica in response to pressure and temperature. Mar. Ecol. Prog. Ser 13: 211-218

Marshall, C. T., Lee, K. (1990). Uptake of dissolved glycine by sea scallop (Placopecten magellanicus) larvae. In: Shumway, S. (ed.) International compendium of scallop biology and culture. World Aquaculture Society and National Shellfisheries Association, Baton Rouge (in press)

Nelson, T C., Perkins, E. B. (1931). Annual Report of the Department of Biology for the year ending June 30, 1930. N. J. Agric. Exp. Sta. Bull. 522: 1-47

O'Reilly, J. E., Evans-Zetlin, C., Busch D. A. (1987). Primary production. In: Backus, R. H., Bourne, D. W. (eds.) Georges Bank, MIT Press, Cambridge, Massachusetts, p. 220-233

Ortner, P. B., Wiebe, P. H., Cox, J. L. (1981). Reply to 'Do oceanic zooplankton aggregate at, or near, the deep chlorophyll maximum?' J. mar. Res. 39: 357-359

Pingree, R. D., Holligan, P. M., Mardell, G. T., Head, R. N. (1976). The influence of physical stability on spring, sum. mer and autumn phytoplankton blooms in the Celtic Sea. J. mar biol. Ass. U. K. 56: 845-873

Posgay, J. A. (1979). Population assessment of the Georges Bank sea scallop stocks. Rapp. P.-v. Réun. Cons. int. Explor. Mer. 175: 109-113

Quayle, D. B. (1952). Structure and biology of the larva and spat of Venerupis pullastra (Montagu). Trans. R. Soc. Edinb. 62: 255-297

Quayle, D. B. (1959). The early development of Bankia setacea Tryon. In: Ray, D. L. (ed.) Marine boring and fouling organisms. Univ. Washington Press, Seattle, p. 157-171

Rice, M. A., Wallis, K. Stephens, G. C. (1980). Influx and net flux of amino acids into larval and juvenile European flat oysters. Ostrea edulis (L.) J. exp. mar. Biol. Ecol. 48: 51-59

Rivkin, R. B., Bosch, I., Pearse, J. S., Lessard, E. J. (1986). Bacteriovory: a novel feeding mode for asteroid larvae. Science 233: 1311-1314

Rothlisberg, P. C., Church, J. A., Forbes, A. M. G. (1983). Modelling the advection of vertically migrating shrimp larvae. J. mar. Res. 41: 511-538

Rothschild, B. J., Osborn, T R. (1988). Small-scale turbulence and plankton contact rates. J. Plankton Res. 10: 465-474

Sameoto, D. D. (1984). Environmental factors influencing diurnal distribution of zooplankton and ichthyoplankton. J. Plankton Res. 6: 767-792

Scrope-Howe, S., Jones, D. A. (1986). The vertical distribution of zooplankton in the Western Irish Sea. Estuar. coast. Shelf Sci. 22: 785-802

Seliger, H. H., Boggs, J. A., Rivkin, R. B., Biggley, W. H., Aspden, K. R. H. (1982). The transport of oyster larvae in an estuary. Mar Biol. 71:57-72

Silva, M. A., O'Dor, R. K. (1988). Active depth regulation by the sea scallop larvae of Placopecten magellanicus? Bull. Can. Soc. Zool. 19 (2): 36 (Abstract)

Southward, A. J., Barrett, R. L. (1983). Observations on the vertical distribution of zooplankton, including post-larval teleosts, off Plymouth in the presence of a thermocline and a chlorophyll-dense layer J. Plankton Res. 5: $599-618$

Sunby, S. (1989). Factors affecting the vertical distribution of eggs and larvae. Symposium on the ecology and management aspects of extensive manculture. Nantes, June 20-23. 1989. Int. Counc. Explor. Sea, p. 1-11

Townsend, D. W., Cucc1, T L., Berman, T (1984). Subsurface chlorophyll maxima and vertical distribution of zooplankton in the Gulf of Maine. J. Plankton Res 6. 793-802 
Tremblay, M. J. (1988). A summary of the proceedings of the Halifax Sea Scallop Workshop, August 13-14, 1987 Can. Tech. Rep. Fish. Aquat. Sci. 1605: $12 p$

Tremblay, M. J., Meade, L. D., Hurley, G. V (1987). Identification of planktonic sea scallop larvae (Placopecten magellanicus) (Gmelin). Can. J. Fish. Aquat. Sci. 44: $1361-1366$

Tremblay, M. J., Sinclair, M. M. (1988). The vertical and horizontal distribution of sea scallop (Placopecten magellanicus) larvae in the Bay of Fundy in 1984 and 1985. J. Northw. Atl. Fish. Sci. 8: 43-53

Turner, J. T., Dagg, M. J. (1983). Vertical distributions of continental shelf zooplankton in stratified and isothermal waters. Biol. Oceanogr. 3: 1-40

Verwey, J. (1966). The role of some external factors in the

This article was presented by $\operatorname{Dr} G$. C. Harding, Dartmouth, N.S., Canada vertical migration of marine animals. Neth. J. Sea Res. 3 245-266

Walne, P. R. (1974). Culture of bivalve molluscs. Fishing News (Books) Ltd., The Whitefriars Press Ltd., London and Tonbridge

Waterbury, J. B. Watson, S. W., Valois, F. W., Franks, D. G. (1986). Biological and ecological characterization of the marine unicellular cyanobacterium Synechococcus. Can. Bull. Fish. Aquat. Sci. 214, 71-120

Wood, L., Hargis, W. J. (1971). Transport of bivalve larvae in a tidal estuary. In: Crisp, D. J. (ed.) Proc. 4 th Eur. Mar Biol. Symp. Cambridge University Press, London, p. 29-44

Wroblewski, J. S. (1982). Interaction of currents and vertical migration in maintaining Calanus marshallae in the Oregon upwelling zone - a simulation. Deep Sea Res. 29: 665-686

Manuscript first received: September 21, 1989

Revised version accepted: December 7,1989 